\title{
Das Proteasom, dein Freund und Helfer
}

So viel Hoffnung neue zielgerichtete Blockadestrategien auch wecken: Für eine nachhaltige

Hemmung - beispielsweise mit Kinaseinhibitoren - bedarf es der Aufrechterhaltung relativ hoher Wirkstoffpegel. Nahezu zwangsläufig erhöht das häufig auch die Toxizität. Wissenschaftler der Yale University in New Haven, CT/USA, setzen deswegen auf eine Strategie, bei der im Zuge der Therapie die blockierten Proteine auch gleich aus dem Verkehr gezogen werden [Salami J, Crews CM. Science. 2017;355(6330):1163-7]. Dazu bedarf es Inhibitoren, die gleichzeitig einen Marker tragen, der sie als reif für die Ubiquitinierung kennzeichnet und damit die anschließende Proteolyse des Targetproteins einleitet. Im Dienst der Proteolyse steht dabei jene komplexe Maschinerie, die sozusagen als Zellpolizei agiert und markierte Proteine effizient abbaut: das Proteasom.

Martin Roos

\section{Ereignisinduzierter Abbau von Proteinen durch das Proteasom}

A: Enzyme mit aktivem Zentrum adressieren: Der Kniff besteht darin, dass der Proteasomaktivierende Blocker (gelb) recycelt wird und so für eine erneute Proteinblockade zur Verfügung steht. Der Wirkstoffbedarf wird so ebenso gemindert wie die Toxizität, so die Idee von Jemilat Salami und Craig Crews. Zwei Beispiele nennen die Forscher: 1. Den Tyrosinkinaseinhibitor Canertinib, der nicht nur ein irreversibler Hemmer von Erb2 ist, sondern auch für die Ubiquitinierung der Rezeptorkinase sorgt, sowie 2. Fulvestrant, das den Östrogenrezeptor alpha (ERa) blockiert, gleichzeitig aber auch das Proteasom aktiviert und damit als ERa-Entsorger wirkt; für die Zukunft setzen Salami und Crews auf eigens konstruierte PROTAC („proteolysis targeting chimeras). Konstrukte mit Dasatinib und Bosutinib scheinen zu funktionieren [Lai AC et al. Angew Chem Int Ed Engl. 2016;55(2):807-10].

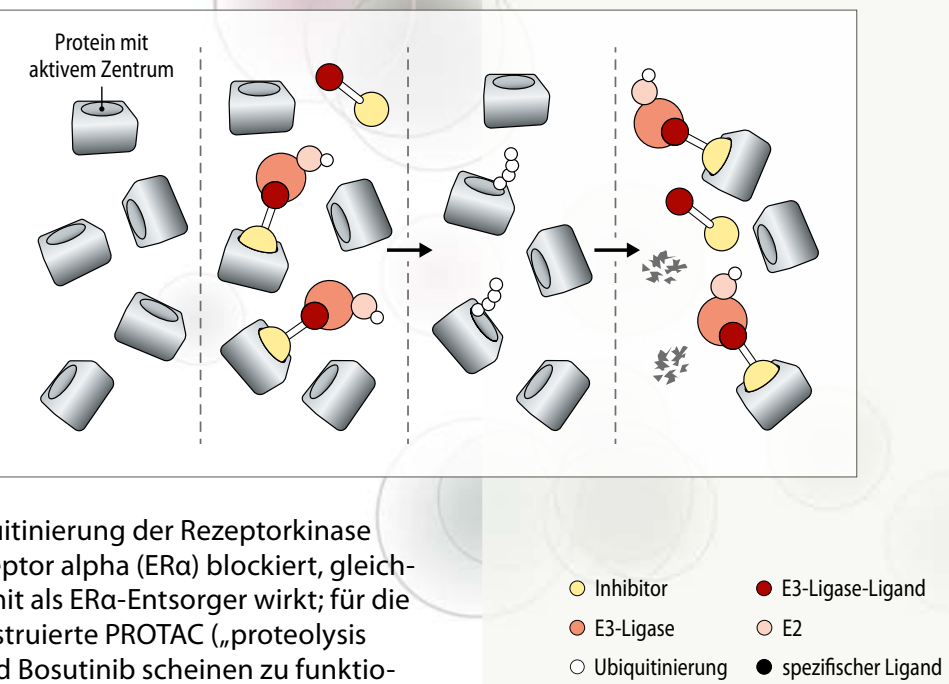

B: Beliebiges Protein mittels eines spezifischen Liganden (schwarz) adressieren: Als Target-Beispiel nennen Salami und Crews hydrophobe Stel-

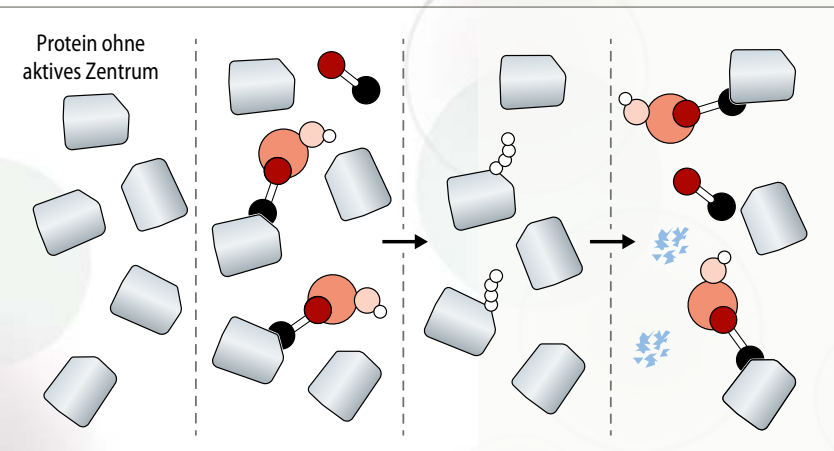
len auf pathologisch falsch gefalteten Proteinen wie dies bei der Pseudokinase Erb3 vorkommen kann [Xie T et al. Nat Chem Biol. 2014;10(12):1006-12]. 